IZA DP No. 4617

New Evidence on the Role of Remittances on Health Care Expenditures by Mexican Households

Catalina Amuedo-Dorantes

Susan Pozo

December 2009 


\title{
New Evidence on the Role of Remittances on Health Care Expenditures by Mexican Households
}

\author{
Catalina Amuedo-Dorantes \\ San Diego State University \\ and IZA \\ Susan Pozo \\ Western Michigan University
}
Discussion Paper No. 4617
December 2009

\author{
IZA \\ P.O. Box 7240 \\ 53072 Bonn \\ Germany \\ Phone: +49-228-3894-0 \\ Fax: +49-228-3894-180 \\ E-mail: iza@iza.org
}

Any opinions expressed here are those of the author(s) and not those of IZA. Research published in this series may include views on policy, but the institute itself takes no institutional policy positions.

The Institute for the Study of Labor (IZA) in Bonn is a local and virtual international research center and a place of communication between science, politics and business. IZA is an independent nonprofit organization supported by Deutsche Post Foundation. The center is associated with the University of Bonn and offers a stimulating research environment through its international network, workshops and conferences, data service, project support, research visits and doctoral program. IZA engages in (i) original and internationally competitive research in all fields of labor economics, (ii) development of policy concepts, and (iii) dissemination of research results and concepts to the interested public.

IZA Discussion Papers often represent preliminary work and are circulated to encourage discussion. Citation of such a paper should account for its provisional character. A revised version may be available directly from the author. 
IZA Discussion Paper No. 4617

December 2009

\section{ABSTRACT \\ New Evidence on the Role of Remittances on
Health Care Expenditures by Mexican Households}

Using Mexico's 2002 wave of the Encuesta Nacional de Ingresos y Gastos de los Hogares $(E N I G H)$, we find that international remittances raise health care expenditures. Approximately 6 pesos of every 100 peso increment in remittance income are spent on health. The sensitivity of health care expenditures to variations in the level of international remittances is almost three times greater than its responsiveness to changes in other sources of household income. Furthermore, health care expenditures are less responsive to remittance income among lower-income households. Since the lower responsiveness may be partially due to participation of lower-income households in public programs like PROGRESA (now called Oportunidades), we also analyze the impact of remittances by health care coverage. As expected, we find that households with some kind of health care coverage - either through their jobs or via participation in PROGRESA - spend less of remittance income increments on health care than households lacking any health care coverage. Hence, remittances may help equalize health care expenditures across households with and without health care coverage.

JEL Classification: F24, I1

Keywords: remittances, health care, household expenditures, Mexico

Corresponding author:

Catalina Amuedo-Dorantes

Department of Economics

San Diego State University

5500 Campanile Drive

San Diego, CA 92182

USA

E-mail: camuedod@mail.sdsu.edu 


\section{Introduction}

Remittances currently account for 2.8 percent of Mexico’s GDP and have doubled in dollar terms from a decade ago. The relative magnitude and the growth rate of these transfers have resulted in a number of inquiries regarding the impact of remittances on migrant households. How are remittances used by the family? Do households use some of these inflows to accumulate human capital and, in particular, health assets as reflected by their health care expenditures? And, if so, how does the responsiveness of health care expenditures to increases in remittance income compare to the responsiveness of health care expenditures to increases in other sources of household income? Are remittances any different from other sources of household income when it comes to financing health care expenditures? Do they contribute towards the equalization of health care expenditures across Mexican households with different income levels and health care coverage?

In this study, we address the aforementioned questions with an analysis of the link between remittance income and health care expenditures by Mexican households. In particular, the study has four objectives: (1) To determine whether and to what extent remittances are used to purchase health care services; (2) To learn about the importance of remittances, relative to other sources of income, in financing households' health care needs; (3) To understand if poorer households are more likely to use remittance receipts to purchase health care services, presumably helping equalize health care use across income groups; and (4) To examine whether remittances are used more intensively for health care by households that do not enjoy health care coverage through a public or private health care insurance program or through participation in a government program like PROGRESA. 
Interest in our first objective -to determine whether and to what extent remittances are used to purchase health care services- originates from the fact that many Mexican immigrants in the U.S. claim that health care expenditures are a primary end for remitting earnings to Mexico. According to data from the Mexican Migration Project (MMP118) in Table 1, approximately 21 percent of Mexicans remitting money home declared health care expenses as their primary motive for their monetary transfers. This percentage is slightly below the percentage who reported remitting for food or maintenance (26 percent) but significantly higher than the percentage of individuals reporting remitting funds for the construction or repair of a house (4.03 percent), debt payment (2.58 percent), and purchase of consumer goods (2.09 percent). Yet, despite the claim that anticipated health care expenditures plays such a significant role with respect to sending money home, we know very little about the true impacts of remittances on health care expenditures. Even if the intended purpose of remittances is to cover health care expenditures as the MMP claims, we do not have confirmation in the MMP of the actual use of remittances by the family members receiving these monetary inflows in Mexico. Hence, we need to observe how households behave in the face of such transfers. If remittances tend to be used for health care, this information should be of interest to policymakers who strive to promote health care in Mexico. This interest is heightened today given the current downturn in U.S. economic activity, which along with more vigorous enforcement of immigration statutes, appears to be threatening the flow of remittances to Mexico. ${ }^{1}$ Learning the extent to which Mexican households rely on remittances to finance health care expenditures can help officials plan for swings in remittance flows and their impacts on health care usage by the Mexican population.

\footnotetext{
${ }^{1}$ See Migration Policy Institute (2007) for evidence of recent declines in remittance inflows at the Mexican-state
} 
Our second objective is to learn about the importance of remittances, relative to other sources of income, in financing households' health care needs. Is one form of income more likely to be used for health care relative to the other? If households receive an additional dollar (peso) in ordinary income, are they more inclined to spend it on health care? Or are remittances more likely to be applied to health expenditures? There are a variety of reasons as for why the responsiveness of household health care expenditures to increases in remittance and nonremittance income might differ. First, remitters may have greater control over how their transfers are spent, thus leading to differences in intra-household bargaining with respect to expenditures using remittance income versus other sources of household income. For instance, remitters may have different spending preferences relative to their family members in Mexico, insisting that a portion of the funds sent home be used to pay for health care needs. The remitter may structure periodic inflows to ensure that his/her desires are carried out. Second, the sensitivity of health expenditures to increases in remittances may differ from increases in ordinary income because of differences in the predictability of the two inflows. If, for example, remittance income is more sporadic or variable relative to other income, remittances might be used differently. Such follows from the idea that unexpected income is more likely to be saved (life-cycle/permanent income hypothesis of Friedman (1957) and Ando and Modigliani (1957)) while less predictable income streams will encourage financial (health) asset accumulation (the precautionary saving motive expressed by Leland (1968)). Regardless of the reason behind the differential propensity to use remittance income versus other ordinary income on health care, understanding differences between the two propensities can inform us on policies more suited to

level. 
alleviating health care deficiencies. If households display a greater propensity to spend on health care from remittance income, it may be worthwhile to adopt policies that encourage and facilitate remittance transfers as a means to promote broader health care coverage while, at the same time, locating health services in migrant-sending regions.

Our third objective is to examine whether remittances can contribute to equalization in the usage of health care services by households across income levels by helping finance the health care expenditures of lower income families to a greater extent than those of their wealthier counterparts. The received wisdom is that, due to income constraints, lower-income households are less likely to obtain adequate health care. Additional inflows can be used to compensate for those deficiencies to a greater extent than in the case of higher-income households; however, this depends on the availability of low-cost health care for lower-income households via public programs like PROGRESA.

Hence, our fourth and final objective is to determine if there are differences in the use of remittances for health care among households with and without some form of health insurance or coverage of health care expenses. While all households in Mexico are eligible for basic health care services through the Mexican Ministry of Health, a significant portion of the population avail themselves of more coverage through participation in additional public or private health insurance programs. Of considerable interest is the ongoing Mexican program Oportunidades (formally PROGRESA) that offers transfers to poor families in return for participating in health and other programs. ${ }^{2}$ This analysis will help us assess whether remittances can contribute to equalization in the usage of health care services by households with and without some kind of 
health care coverage by helping finance the health care expenditures of families lacking any type of health care coverage.

We find that remittances are partially used to pay for health care expenditures. Approximately 6 pesos out of 100 pesos of remittance income increments are spent on health care. Furthermore, health care expenditures are more responsive to changes in remittance income than to changes in other sources of household income. Only 2 pesos out of 100 peso increments in other sources of household income are spent on health care. Additionally, while health care expenditures exhibit greater remittance income sensitivity among households in the top half of the income distribution, health spending is more responsive to remittance increments among households without any health care coverage. Because poorer households are more likely to be enrolled in PROGRESA, which offers cash transfers conditional on participation in health and nutrition programs, it is reasonable for higher-income households to spend a larger fraction of their remittance income on health care than lower-income households with covered health care needs. Overall, our findings add to the growing evidence of the potentially crucial role of remittances in migrant-sending communities.

\section{Background and Literature on Health Care, Migration and Remittances}

In 2002, Mexico spent 6.1 percent of its GDP on health, a significantly smaller amount than the 14.6 percent of GDP spent on health by the United States (WDI 2005). But what is even more noteworthy is that while Mexico ranks first in Latin America with respect to per capita GDP, it lags behind the Latin American average in terms of health care expenditures. On

\footnotetext{
${ }^{2}$ PROGRESA and Oportunidades transfers are conditioned on recipients' participation in basic health and nutrition programs, as well as on children's educational attainment.
} 
average, health care expenditures account for 6.8 percent of GDP in Latin America (WDI 2005), a slightly more generous amount in comparison to Mexico’s 6.1 percent.

While Mexican families with members employed in the formal sector generally receive health care services through Mexico's social security system, the unemployed, informal and selfemployed workers and their families (referred to as the uninsured) are relegated to obtaining basic and often incomplete health care through the Ministry of Health. To partially address deficiencies in proper access to health care services, the Mexican government implemented PROGRESA (now called Oportunidades) in 1997 in selected areas of the country. PROGRESA offered cash transfers to poor families in Mexico conditional on their participation in health and nutrition programs. Specifically, families enrolled in PROGRESA were required to participate in prenatal care programs, well-baby care and immunization, nutrition monitoring and supplementation, and preventive health care programs. ${ }^{3}$ While the size of the covered population, as well as the list of illnesses and medicines covered by government programs have been rapidly expanding, ${ }^{4}$ this form of insurance still fails to provide the same coverage provided to formal sector workers and their families. Consequently, it is reasonable to ask the degree to which remittances impact health care expenditures.

In analyzing the role that remittances may play in the provision of health care, it is important to consider the relationship between migration and health. A small literature addresses

\footnotetext{
${ }^{3}$ However, as of 2002, it was still estimated that between 40 and 60 percent of the Mexican population was “uninsured” (Secretaría de Salud 2002, Frenk et al. 2003).

${ }^{4}$ In 2005, with the purpose of addressing the still large number of uninsured individuals, the Mexican government approved Seguro Popular, a narrower program that is intended to simply focus on increasing access to health care services. There is no condition to participate aside from a small yearly premium, which then gives participants the right to specified health services. By the end of 2007, over 7 million families were covered by Seguro Popular and over time the program is expected to encompass more segments of the population (Secretaría de Salud 2008 at http://www.seguro-popular.salud.gob.mx/).
} 
health outcomes among households in which some members have migrated. A number of the studies conclude that migration of a household member results in poor health outcomes for the non-migrating family members. Using the MMP, Kanaiaupuni and Donato (1999) attribute increases in infant mortality to family separations. The transmission of habits and lifestyles (social remittances) that may be incompatible with healthy outcomes may further disadvantage health in families with migrating members (Levitt 1997). Finally, migration may contribute to poor health outcomes in communities that experience much out-migration on account of the importation of communicable diseases, such as tuberculosis or HIV (Perez-Stable et al. 1986).

While these studies speak to the unfavorable impacts of migration on health outcomes, many studies also note that migration has the potential to improve health outcomes for the families that remain behind. For instance, Levitt (1997) argues that improved health behaviors can also be remitted "socially" leading to improved health outcomes. Likewise, Frank and Hummer (2002) measure higher birth weights in families with a migrant member -possibly due to the acquisition of positive health behaviors from migrants.

In addition to migration, monetary transfers or remittances can affect health by relaxing liquidity constraints that would otherwise restrict access to health care. Kanaiaupuni and Donato (1999) argue that, despite the initial disruptive effects of family separations, over time, as migration becomes "institutionalized" and the household receives monetary remittances, infant mortality significantly drops. In the same vein, López Cordova (2004) takes advantage of variability in remittance receipt rates across Mexican municipalities and concludes that remittances lower infant mortality rates. Hildebrandt and McKenzie (2004) link increased birth weight and lowered infant mortality rates to both monetary remittances and health knowledge, 
whereas Duryea, López-Córdova and Olmedo (2005) conclude that the acquisition of better housing infrastructure (e.g. improved housing, water and refrigeration of food) via remittances is crucial in reducing infant mortality.

Also looking at the impact of remittances in Mexico, Amuedo-Dorantes et al. (2007) and, more recently, Valero-Gil (2008), find that remittances raise health expenditures in Mexico. Amuedo-Dorantes et al. (2007) take a first look at the ENIGH data to examine how remittances affect household expenditures on specific health care services, from routine primary care to hospitalizations. Using instrumental linear regression methods, they find that hospitalization expenditures display the largest responsiveness to remittance income. However, primary care expenditures are also higher among remittance-receiving households who, on average, spend between 5 and 9 percent of their remittances on primary care services. Yet, their analysis falls short of gaining a better understanding of whether Mexican households are likely to use remittances, as opposed to other sources of income, to purchase health care services, as well as to how these propensities to consume remittances to purchase health care services differ according to household income strata and health care coverage. Valero-Gil (2008), also using the ENIGH, estimates that one-tenth of remittances are spent on health expenditures in Mexico. Yet, his analysis does not address the endogeneity of remittances with respect to household expenditures.

Summarizing, the relatively small literature on this topic appears to have focused on the link between migration and health outcomes, with only a handful of studies zeroing in on the actual link between the receipt of remittances and health outcomes. While the improvement of health outcomes is society's ultimate goal, understanding the impact of remittance income on health care expenditures is also of great importance as it relates to a topic of considerable policy 
interest, i.e. how remittances are being used in developing countries. To this end, we follow up on the existing literature and further examine how remittances impact health care expenditures.

\section{Modeling Health Care Expenditures}

We briefly outline a standard model of the demand for medical care based on the model of the demand for health developed by Grossman (1972) in which we incorporate any remittance inflows received by households. The starting point in this model is a health production function: $H=g\left(m, Z_{H}\right)$, where $m$ stands for medical care and the vector $Z_{H}$ includes a variety of factors affecting the production of health along with medical care $(m)$, such as (but not limited to): demographic and economic characteristics (e.g. age, education, household composition and wealth), stock of health (e.g. weight and information on family health-related endowments), and family lifestyle (e.g. diet, exercise patterns, or smoking/drinking/drug use habits).

Consumers (in our case households) are assumed to maximize a utility function, $U=U(X, H)$, that depends on the consumption of two normal goods: $X$ (market goods) and health $(H)$. Each household tries to maximize its utility by reaching the highest indifference curve possible subject to a budget constraint. In our case, the budget constraint is a function of remittances from abroad $(R)$ which, along with other sources of income (I), are used to pay for $X$ (with price $P_{x}$ ) and for any medical care $(m)$ (priced at $P_{m}$ ) used to produce health $(H)$ as follows: $P_{x} X+P_{m} m \leq I+R$. From the previously described tangency, we derive an equilibrium combination of market goods and medical care: $\left(X_{0}, m_{0}\right)$, where $m_{0}$ stands for the equilibrium demand for medical services measured by health care expenditures. Therefore, households' health care expenditures depend on: 


$$
H C E=f\left(R, I, P_{X}, P_{m}, Z_{H}\right)
$$

where $P_{m}$ itself is likely to vary according to a variety of factors, such as proximity and availability of health care services, health care insurance, or household participation in government programs providing some health care coverage (e.g. PROGRESA).

Increases in remittance income are equivalent to increases in non-labor income which, other things equal, should shift the household's budget constraint outwards in a parallel fashion. Because only household non-labor income would be changing, an increase in remittance income should result in an income effect according to which the household would enjoy a higher disposable income enabling it to reach a higher indifference curve. The new tangency should result, ceteris paribus, in a higher consumption of $X$ and $m$-both normal goods. We test whether, as predicted by the theory, an increase in remittance income raises health care expenditures (via an increase in the household's medical use) and, if so: (i) to what extent, and (ii) how the change in health care expenditures due to an increase in remittance income compares to the impact of similar increases in other sources of household income.

\section{Data}

The empirical analysis uses data from the Encuesta Nacional de Ingresos y Gastos de los Hogares (ENIGH), a nationally representative survey carried out by the Mexican statistical institute, Instituto Nacional de Estadística, Geografía e Informática (INEGI), with the purpose of providing information on the size, structure, and distribution of Mexican households' income and expenditures. The survey is intended to be nationally representative and distinguishes households in rural areas (fewer than 2,500 inhabitants) from households in urban areas (more than 2,500 inhabitants). The first wave of the survey was administered in 1984 and it has been 
carried out biennially since 1992. In this project, we use the 2002 survey, which provides more up to date and reliable data on remittance receipts and health care expenditures. ${ }^{5}$

In addition to general socio-demographic and employment information on household members, the survey collects detailed information on all income flows (net of taxes) received by the household over the past six months, including international money transfers, earnings from employment and from self-employment, asset income, and income from domestic transfer programs. Other Mexican surveys containing nationally representative information are not suitable for carrying out this analysis. The Mexican Life Family Survey does not distinguish domestic from international remittances and the Mexican Census, while providing information on remittance receipts, does not ask about health care expenditures or other spending patterns.

In Table 2 we provide some descriptive information on the frequency and levels of the various sources of income in order to better appreciate their relevance for households. After purging outliers from our sample, ${ }^{6}$ we divide households in the ENIGH into two broad income groups: (i) those that earn the median income or less, and (ii) those that earn more than the median income. ${ }^{7}$ We then present descriptive information for all households as well as for lower-income and higher-income households. Overall, household income composition is as expected. For instance, jobs are the most frequent source of household income with 71 percent of all households reporting earnings from employment. Business earnings constitute the third most frequently reported source of income, with 45 percent and 39 percent of households in the

\footnotetext{
${ }^{5}$ Table A in the appendix contains the descriptive statistics of the variables used in the analysis.

${ }^{6}$ We delete those observations in the top 2 percent of the remittance income and other household income distributions in order to eliminate a number of implausible observations.

${ }^{7}$ The division of households into lower-income and higher-income groups is determined by summing all sources of household income, except for remittance income. Households with total incomes (excluding remittance income)
} 
lower and upper half of households, respectively, receiving some entrepreneurial income. Lower-income households appear more likely to receive domestic income transfers than higherincome households (45 percent versus 25 percent). In contrast, capital and property returns are more frequently reported by higher-income households. Not surprisingly, remittances are skewed towards the less advantaged, with two percent of higher-income households receiving remittances from abroad compared to eight percent of lower-income households. Finally, looking at mean receipts (that is, conditional on receiving that particular type of income inflow), we find that remittances contributed the least to household income among higher-income households. However, remittances amounted to the second most important source of income for households in the bottom half of the income distribution.

The ENIGH also contains detailed information on a variety of household expenditures. Of interest to this study are health care expenditures for the entire household during the previous three months. As shown in top panel of Table 3, about 57 percent of households (a total of 9,582 out of 16,810 households in the survey) reported using medical services over the survey's previous 3-month period in 2002. Yet, due to the availability of publicly provided medical services, health care expenditures only amounted to 5 percent of total household income (i.e. 796 pesos out of an average household income of 16,141 pesos in Table A). The figures in Table 3 summarize health care expenditures according to various household characteristics. Households residing in rural areas, families headed by women, less educated household heads, and households in the bottom half of the income distribution, are all less likely to use health care services than their corresponding counterparts. In addition, their average health care 
expenditures in pesos are, correspondingly, lower than those incurred by households in urban areas, by families with more educated household heads and by households in the upper half of the income distribution.

Of particular interest to us is the effect of remittances on the usage of health care services. According to the figures in Table 3, remittance-receiving households are more likely to use health care services and they also spend more on health care. However, this result is solely conditioned on household remittance receipt, ignoring other concurrent household traits that may lead to differential health care usage of remittance-receiving households and households lacking such receipts. In what follows, we describe the methodology employed to help us examine the role of remittance income on household health care spending.

\section{Methods}

As with other production and investment activities (Stark 1982, Taylor 1992, Rozelle et al. 1999), health care expenses (HCE) are constrained by remittance income $(R)$ and a vector $Z_{H C E}$ that incorporates information on a variety of covariates thought to be important determinants of household health care expenditures, such as: household income $(I)$, cost of medical care $\left(P_{m}\right)$, cost of other goods and services consumed by the household $\left(P_{X}\right)$, and all the characteristics included in $Z_{H}$ in equation (1) thought to affect the production of health. Therefore, household health care expenses can be modeled as follows:

(2) $\quad H C E=\alpha_{0}+\alpha_{1} R E+Z_{H C E} \alpha_{2}+\varepsilon_{H C E}$.

However, in estimating health care expenditures and examining how remittance income and other sources of household income affect such expenditures, there are various econometric

remittance income) above the median are considered higher-income households. 
issues we need to take into account. One of the problems refers to the potential correlation between household remittances and the error term, in which case the coefficient estimate for remittance income is biased. There are two potential sources for this noted correlation. The first source originates in the presence of unobserved heterogeneity and omitted variable bias. Household remittances may be related to a wide range of characteristics we lack information on, ranging from household wealth (as captured by ownership of a house, piece of land, business, livestock or some other physical asset) to the family's health stock which, in turn, can impact household health care expenditures. Those correlations may result in either positively or negatively biased estimates of the impact of remittances on health care expenditures. ${ }^{8}$

The second source of potential correlation between household remittances and the error term in equation (2) results from the joint determination of household remittance income and health care expenditures. We address the simultaneous determination of household remittance income and health care expenditures by using information on lagged household remittance income. Specifically, we model health care expenditures in the past quarter (e.g. quarter 2) as a function of the receipt of remittances during the preceding three-month period (e.g. quarter 1). Yet, while predetermined, household remittances and household health care expenses may still be endogenous due to remaining unobserved heterogeneity and omitted variable biases. Hence, we also make use of instrumental variables to address the endogeneity of remittance income.

\footnotetext{
${ }^{8}$ As noted by Wooldridge (2003, pp. 89-93), the sign of the omitted variable bias depends on the sign resulting from interacting the expected sign of the coefficient that the omitted variable would have in the health care expenditure equation (i.e. $\beta_{\text {wealth }}>0$ or $\beta_{\text {Healt }}<0$ ) and the sign of the correlation between remittances and the omitted variables in question (e.g. $\operatorname{corr}(R E$, wealth $)<0$ and $\operatorname{corr}(R E$, Health) $<0$ ). Hence, depending on the relevance of various omitted variables in driving both household remittances and health care expenditures, the bias can either be positive (as in the case of missing information on the household's health stock) or negative (as in the case of missing information on household wealth).
} 


\section{A) Modeling Household Remittance Income}

We address the endogeneity of remittance income using an instrumental variable approach. We instrument remittance income with its predicted value as derived from a model of remittance receipts. Because only 5 percent of households receive remittance income, the distribution that applies to $R$ is both discrete and continuous. In such cases, an option is to use selection models (such as the Heckman-type model) where one first estimates the likelihood of receiving remittances using a probit model. Subsequently, using a slightly different set of covariates to allow for the identification of the likelihood of remittance receipt model, one can model the peso figure remitted while accounting for the sample selection that occurs when focusing on remitters by OLS (e.g. Hoddinott 1994, Funkhouser 1995, Cox et al. 1998). This type of modeling has the advantage of allowing the likelihood of remittance receipt to be shaped by different variables from those determining the peso amount received from abroad by the household. However, the results from such models are sensitive to identification exclusions that are debatable given the difficulty of envisioning factors that affect the likelihood of remittance receipt, yet have no influence on the remittance amount received by the household.

An alternative that allows us to circumvent this identification problem is to use a Tobit model (Brown 1997, Ravallion and Dearden 1998, Schrieder and Knerr 2000). The Tobit model allows us to account for the discrete and continuous nature of the distribution of remittance income while modeling the likelihood of remittance receipt and the peso amount received by the household as a function of the same covariates. One disadvantage of the Tobit model is that the regressors shaping the likelihood of remittance receipt and the amount finally received have the same signs. However, as noted by Wooldridge (2003, p. 573), it is possible to informally assess 
the appropriateness of the Tobit model for our analysis by estimating a separate probit model of the likelihood of remittance receipt and comparing the sign and magnitude of the coefficients of the statistically significant explanatory variables in that model to the coefficients in the Tobit model. We do so and, given the similarity of the results, we choose to predict remittance income receipts using a Tobit specification where remittances are determined as follows:

$$
R^{*}=\beta_{0}+Z_{R} \beta_{1}+\varepsilon_{R} \text { with } R=\max \left(0, R^{*}\right) \text { and } \varepsilon_{R} \sim \mathrm{N}\left(0, \sigma^{2}\right) \text {. }
$$

The vector $Z_{R}$ incorporates information on a variety of covariates thought to be important determinants of household remittance income receipt (see Table B in the Appendix). including household composition variables, the educational attainment of household members and household income excluding remittances. Additionally, we account for the extent of outmigration in the state of residency as captured by the percent of the state's population that has emigrated to the U.S. in the past. In this manner, we capture the important role played by networks in facilitating the out-migration of household members likely to remit money home in subsequent periods.

In addition to the aforementioned regressors, all of which can also be argued to impact household health care expenditures, equation (3) needs to include at least one variable -an instrument (or IV)- that is correlated with household remittance income but not with household health care expenditures. That instrumental variable should be adequately excluded from the main equation modeling household health care expenditure for identification purposes. We select two variables to be included in $Z_{R}$ as instruments: the road distance in kilometers to the U.S. border (from the capital of the Mexican state in which the household resides) and U.S. wages in Mexican emigrant destination states. Information on the road distance to the U.S. 
border is readily available from a road atlas. However, because the ENIGH does not have any information regarding household emigration, we exploit information on state-level migration networks to derive information about the U.S. wages earned by Mexican emigrants from the various Mexican states included in the survey. Specifically, we use data from the Mexican Migration Project to determine the most common U.S. destinations for emigrants from each of the Mexican states in the ENIGH survey. We then use this information to construct weighted averages of 2002 U.S. wages for the stock of emigrants from each of the Mexican states. ${ }^{9}$

What is the logic behind our choice of instruments? Road distance in kilometers to the U.S. border and U.S. wages in Mexican emigrant destination states can be argued to be closely linked to the dollar amounts received by household members in Mexico. Distance can raise the cost of sending money home -especially in the case of hand carried informal transfers. Distance also weakens family ties, resulting in lower remittance receipts. On the contrary, higher wages in U.S. destination areas will likely raise emigrants' disposable earnings and increase the likelihood and level of remittances sent home. Furthermore, both instruments are unlikely to represent individual household preferences owing to the way in which they are defined. Distance to the U.S. border is measured from the state capital; therefore, it does not reflect any particular household residential location preference. Likewise, U.S. wages in Mexican emigrant destination states are derived from information on state-level migration networks from a different survey and, as such, do not directly reflect choices made by the individual households contained in our survey.

\footnotetext{
${ }^{9}$ For example, in the state of Durango, the MMP indicated that in 2002 about 31 percent of emigrants resided in California, 28 percent resided in Texas and 26 percent in Illinois. Therefore, we compute the average U.S. wage for emigrants from Durango as follows: [0.31*(California wages in 2002) $+0.28 *($ Texas wages in 2002) $+0.26 *(I l l i n o i s$ wages in 2002) $+0.15 *$ (average U.S. wages in 2002)].
} 
Our identifying assumption is that road distance to the U.S. border and U.S. wages do not affect the health care expenditures of Mexican households. One potential threat is that the instruments may be related to household characteristics that affect their health care expenditures, such as household out-migration and household wealth. ${ }^{10}$ A second possible threat to the validity of our instruments could come from the fact that Mexican migrants from different regions may traditionally send migrants to specific U.S. states. In that case, the instruments could be just capturing regional differences across Mexican states which result in different outmigration patterns that are, in turn, correlated with household health care expenditures. Unfortunately, the ENIGH lacks information on household emigration and wealth. However, in addition to accounting for as many household characteristics correlated with emigration and wealth as possible (such as household education and income), we include information on per capita GDP at the state level, as well as on the extent of out-migration in the state as captured by the percent of the state's population that has emigrated to the U.S. in the past. Per capita GDP captures differences in the standard of living in each state, which are possibly correlated to outmigration patterns, e.g. maybe richer states have migrants in U.S. states that are farther away from the border or in U.S. states where earnings are higher. In turn, the percent of migrants in the state addresses the important role played by networks in facilitating the subsequent outmigration of other individuals in the community to a particular location in the U.S. In this manner, we also account for any community network effect on household health care practices and expenditures which, in any event, is likely to be second-order (to the effect of other household characteristics) in household health care expenditure decisions.

\footnotetext{
${ }^{10}$ For instance, wealthier households to be more likely to place migrants in economically more attractive U.S. states.
} 
We also thoroughly inspect both instrumental variables to ascertain their suitability as instruments from an econometric point of view. First, we examine whether they are significantly correlated with household remittance income -the endogenous regressor to be instrumented. As we shall discuss in what follows, our instruments help explain the peso amount received by households from abroad at the 5 percent significance level, suggesting that there is a strong correlation between the instruments and household remittance income. Secondly, we assess the exogeneity of our instruments to the extent this is possible. A priori, there is no theoretical reason to believe that our two instruments would affect household health care expenditures other than through the receipt of remittances -our endogenous regressor. Indeed, remittances can impact household health care expenditures via a higher purchasing power that enables the household and community to access better health care. The model already accounts for the role played by monetary remittances, which is the variable we are trying to instrument for. Alternatively, remittances are accompanied by the transmission of health knowledge and lifestyles on the part of migrants. However, the vector $Z_{R}$ already includes information on the extent of out-migration in the state of residency, which is likely to serve as a good proxy for these effects. Nonetheless, as an informal check, we estimate our health care model including all its regressors, along with remittance income and the two instruments being used. Neither instrument appears to have a significant direct impact on health care expenditures once we control for household remittance receipts. ${ }^{11}$ Finally, since remittance income is being instrumented by two variables, we use over-identification tests to examine the exogeneity of the instruments. Because of existing concerns regarding the low power of these tests in case of

\footnotetext{
${ }^{11}$ Results are available from the authors.
} 
general misspecifications (e.g. Newey 1985), we use Sargan’s (1958) as well as a recommended variation of the Basmann (1960) test -the Basmann-LIML form of the test (see Staiger and Stock 1997). Both tests examine the exogeneity of instrument conditional on the other one being valid. That is, in both tests, the null hypothesis is that the omitted instrument is uncorrelated with the error term and correctly excluded from the estimated equation. However, to the extent that the rationale for the two instruments is similar, (i.e. the U.S. location choices of Mexican emigrants) non-rejection of the null hypothesis is likely to support the validity of both instruments (Baum et al. 2002, Woodridge 2003). As shown in Table 4, we are unable to reject the null hypothesis, which suggests that our instruments are valid from an econometric perspective. Nevertheless, we carry out the analysis with and without instrumental variables to help us sign the direction of the bias in our remittance income estimates.

\section{B) Modeling Household Health Care Expenditures}

In order to measure the responsiveness of household health care expenditures to

remittance income, we derive predicted household remittance income $(\hat{R})$ from equation (3) and use it to instrument for remittance income in equation (4), which models household health care expenditures as follows:

$$
H C E=\alpha_{0}+\alpha_{1} \hat{R}+Z_{H C E} \alpha_{2}+\varepsilon_{H C E}
$$

Once more, as in the case of remittance income, we are confronted with the fact that HCE equals zero for a large number of households (almost half of the sample according to the figures in Table A in the appendix). Additionally, our dependent variable is highly skewed and approximately log-normally distributed. Many papers have discussed the difficulties of properly modeling medical expenses, making it impossible to credit them all here (e.g. Duan et al. 1983 
and 1984, Hay and Olsen 1984, Manning 1998 and Mullahy 1998, among many others). Nonetheless, let us start by saying that using a Tobit model to estimate equation (4) would be inappropriate for a number of reasons, including the fact that the Tobit model assumes that a single mechanism determines both likelihood as well as the peso amount spent on health care. (i.e. $\partial P\left(H C E>0 \mid Z_{H C E}\right) / \partial z_{j}$ and $\partial E\left(H C E \mid Z_{H C E}, H C E>0\right) / \partial z_{j}$ are constrained to be both negative or both positive). But, unlike for remittances, we can easily foresee the possibility that different mechanisms govern the likelihood of incurring any health care expenditure and the peso amount spent on those services (e.g. health care coverage via insurance or PROGRESA).

An alternative to using a Tobit model is the self-selection or Heckman model. However, as noted by Duan et al. (1983), among other authors, the self-selection model is rejected for various reasons, such as: (a) assuming that the functional form is known a priori and that it yields a bivariate normal error; (b) estimating unconditional (uncensored) expenditures when, in fact, the zeros in health care expenditures are true zeros and not merely missing information; and (c) displaying poor numerical and statistical properties (in particular, the inability to separate selection effects from heteroscedasticity and nonlinearity).

Therefore, we opt for a simple two-part model where the initial likelihood of using health care services and products during the past three months is separated from the process determining overall household health care expenditure amounts. In the first part of the model, we estimate the likelihood of encountering any health care expenditure via a probit model as follows:

$$
P\left(H C E=0 \mid \hat{R}, Z_{H C E}\right)=1-\Phi\left(\alpha_{0,1}+\alpha_{1,1} \hat{R}+Z_{H C E} \alpha_{2,1}\right), \varepsilon_{H C E, 1} \sim N(0,1)
$$


Subsequently, in the second part of the model, we model household health care expenditures during the past three months for households encountering health care expenditures as follows:

$$
\log (H C E \mid H C E>0)=\alpha_{0,2}+\alpha_{1,2} \hat{R}+Z_{H C E} \alpha_{2,2}, \varepsilon_{H C E, 2} \sim \operatorname{Normal}\left(0, \sigma^{2}\right)
$$

As noted by Duan et al. (1983), among others, equations (5) and (6) can be estimated separately by maximum likelihood. In computing meaningful marginal effects, we address two problems that arise in the re-transformation process: (1) $\varepsilon_{H C E, 2}$ may not be homoscedastic and (2) $\varepsilon_{\mathrm{HCE}, 2}$ may not be Normally distributed. We first test for heteroscedasticity in $\varepsilon_{\mathrm{HCE}, 2}$ and are unable to reject the null hypothesis of homoscedasticity regardless of whether we instrument for remittance income or not. ${ }^{12}$ Next, we test for the Normality of the log-scale error term and conclude that it is not Normal. ${ }^{13}$ We thus address the non-Normality of the error term when the latter is homoscedastic using Duan's (1983) smearing estimator.

\section{Results}

In order to gain some insight into the impact of remittances on health care expenditures, we first examine how these monetary inflows impact both the likelihood of incurring health care expenditures and the peso amount spent on health care. Namely, do remittances increase spending on health care, and if so, to what degree? Secondly, we compare the sensitivity of health care expenditures due to changes in remittance income to their sensitivity to changes in other sources of household income. If remitters earmark the funds sent home for specific

\footnotetext{
${ }^{12}$ Using the Breusch-Pagan/Cook-Weisberg test for heteroscedasticity (where: $\mathrm{H}_{0}$ :constant variance), we get a test statistic: Chi2(1) $=0.27$ with Prob $>$ Chi2 $=0.6034$ when we do not instrument remittance income and a test statistic: Chi2(1) $=0.40$ with Prob $>$ Chi2=0.5283 when we do. Hence, in both instances, we fail to reject the null hypothesis of a homoscedastic error term.
} 
purposes -such as covering health care needs, and can monitor those expenditures, we may observe a greater responsiveness of health care expenditures to monetary inflows from family abroad than to other sources of household income. Alternatively, differences in the time pattern of receipts may result in different expenditure patterns. Finally, we disaggregate the data according to whether the household's income is below or above the median income for households in our sample in order to gain insights into differential impacts by income levels. Do remittances help even out health care expenditures across income groups by raising health care expenditures among poorer households to a greater extent than among their wealthier counterparts? Because many lower-income households participate in public programs covering some basic health care needs (as is the case with PROGRESA that covers prenatal care, wellbaby care and immunization, nutrition monitoring and supplementation, and preventive checkups), while some higher-income households are likely to enjoy other forms of health care coverage through public or private insurance provided through their jobs, it is also of interest to examine the impact of remittance income on health care expenditures distinguishing households according to their health care coverage. Hence, we group households according to whether they have any form or health care coverage (via PROGRESA or via private or public insurance offered through their jobs). Then, we examine how, once we control for household income, remittances help equalize health care expenditures across households with and without health care coverage by raising the health care expenditures of households with no health care coverage to a greater extent than those of households with some form of health care coverage.

\footnotetext{
${ }^{13}$ The skewness/kurtosis tests for Normality indicate that the log-scale error is not Normal with Prob $>$ Chi $2=0.0000$ regardless of whether we instrument or not for remittance income. Hence, in both instances, we reject the null hypothesis of a Normally distributed error term.
} 
Because remittance income may be endogenous to health care expenditures, we first estimate a Tobit model (equation 3) to derive the predicted levels of household remittance income per quarter. These predictions are later used in place of household remittance income in the estimation of the two-part instrumental variable models of health care expenditures. The results from estimating equation (3) are displayed in Table B in the appendix. Of particular interest to us is the statistical significance of distance from the U.S. border and average wages at the U.S. destination state -our instruments - after accounting for a range of household characteristics, including their state's out-migration rate. They both have the expected signs (that is, remittances decrease with distance from the U.S. border and increase with wages in U.S. destination states) and are statistically different from zero at the 5 percent level. ${ }^{14}$

\section{A) Responsiveness of Health Care Expenditures to Remittance Income}

Our first objective is to examine whether remittances are used to purchase health care services and, if so, to what extent. The figures in Table 4 help us answer that question. Table 4 reports the results from estimating two-part models of health care expenditures incurred by households with and without instrumenting for remittance income. Aside from the slightly larger magnitude of the IV estimates signaling the downward bias of the non-IV estimates, ${ }^{15}$ the non-

\footnotetext{
${ }^{14}$ Other findings are as expected. For instance, female headed households, larger families, and households with a larger number of young children or elderly members receive greater remittance transfers. In particular, female headed households receive 105 more pesos per quarter relative to male headed households. Each additional household member raises remittance inflows by 18 pesos per quarter (although elderly members raise household health care expenditures to a greater extent than young children). Additionally, families residing in rural areas, in states that have experienced more out-migration, and in states where emigrants earned higher U.S. wages also enjoy larger transfers. In contrast, richer households, households with more working members, as well as those living further from the U.S. border, receive smaller remittance transfers from abroad than poorer households, households with fewer working members, and households closer to the U.S. border, respectively.

${ }^{15}$ As noted earlier, the non-IV estimates are likely to be biased owing to the endogeneity of remittances stemming from omitted variables biases. In this particular case, the non-IV estimates appear to be biased downwards. This means that variables, such as household wealth (in the form of housing, land or similar assets), which are positively
} 
IV and IV estimates are qualitatively similar as reflected by their signs and significance levels. Of particular interest to us is the potential impact of remittance income on health care expenditures, which appear to rise with income transfers from abroad in both the instrumented and non-instrumented estimations. A 100 peso increment in remittance income raises health care expenditures anywhere between 5 and 6 pesos, depending on whether we refer to the noninstrumented or the instrumented results. ${ }^{16}$

\section{B) Responsiveness of Health Care Expenditures to Other Sources of Household Income}

Our second objective is to learn about the importance of remittances, relative to other sources of income, in financing households' health care needs. Is one form of income more likely to be used to finance health care expenditures than the other? Is health spending more sensitive to monetary inflows from family abroad than to other sources of household income? By comparing the marginal effect of increments in remittance income and in income excluding remittances we can determine the relative sensitivity of these expenditures to the two sources of income.

linked to health care expenditures, yet inversely related to remittance inflows, play a significant role in downward biasing the non-IV estimates.

${ }^{16}$ Other variables also display the expected effects. For instance, increments in other sources of household income also raise health care expenditures as would be expected for a normal good. Female headed households are less likely to incur health care expenditures; however, their health care expenditure amounts do not seem to significantly differ from those of non-female headed households. In contrast, the number of young children and the number of elderly members raise both the likelihood of incurring health care expenditures as well as their levels. It is, perhaps, for the same reason that, while a larger number of working members increases the household's financial access to health care and, as such, the likelihood of incurring such expenses, a larger number of working individuals -who are less likely to be young children or elderly members- is associated with lower household health care expenditures. Finally, household location matters. Rural households incur smaller health care expenditures than urban households, possibly due to differences in the proximity and availability of health care services. Additionally, households residing in Mexican states with more out-migration are more likely to incur health care expenditures and spend more on such services. This could be, in part, due to the transmission of health knowledge and the dissemination of certain health practices and behaviors by migrants to their families back home (Kanaiaupuni and Donato 1999, Frank and Hummer 2002). Lastly, households in richer states, as captured by their per capita GDP, are also more 
The figures in Table 4 indicate that a 100 peso increase in income raises expected health care expenditures by approximately 2 pesos. This is much less than the 6 peso increment resulting from a 100 peso increase in remittances. Therefore, the responsiveness of health care expenditures to increases in remittance income is about 3 times greater than the responsiveness to similar increases in other sources of household income. What might explain this finding? Perhaps, remitters do have preferences that differ from those of their households back home and are able to control, from afar, the use of the funds they send. In any event, the greater responsiveness of health care expenditures to increases in remittance income than to increases in other sources of household income is not surprising considering that up to 21 percent of remitters in the MMP claim health care to be a primary motive for sending money home. Health care seems to be a priority for migrants.

\section{C) Responsiveness of Health Care Expenditures by Household Income Level}

Due to deficiencies in access to financial markets, remittance income may play a crucial role among lower-income households facing greater budgetary constraints than among higherincome households. Hence, our third objective is to learn about how remittances impact health care expenditures of lower-income versus higher-income families. To do so, we first divide our sample into lower-income (households with incomes below or equal to the median income) and higher-income (households with incomes above median income) groups and re-estimate the health care expenditure model for the two groups. ${ }^{17}$ As when working with all households in

likely to spend on health care even if, possibly linked to differences in their health practices or access to coverage, their health care expenditures appear to be slightly lower.

${ }^{17}$ Because the division of households by income may seem arbitrary, we also distinguish households according to whether their incomes fall below or above the mean. Likewise, we also try limiting the analysis to households in the lowest and highest income quartiles. Our results are robust to these alternative specifications. 
Table 4, we display the results from estimating two-part models of health care expenditures when we do not instrument for remittance income and also when we do. For the sake of brevity, we report the coefficients, standard errors, and marginal effects for remittance income and for ordinary income only. ${ }^{18}$

As in Table 4, the responsiveness of household health care expenditures to increases in remittance income is greater (between two and three and a half times larger) than its responsiveness to other sources of household income. However, health care expenditures are more responsive to increases in remittance income in richer households than in lower-income households. Approximately 4 pesos from a 100 peso increase in remittance income are spent on health care in lower-income households as opposed to 7 pesos in higher-income households. Why might this be the case? Perhaps higher-income households spend more on health care because they are not as resource constrained as lower-income households. Remittance income may be used for more pressing needs in lower-income households. Alternatively, lower-income groups may have access to cheaper medical care (through PROGRESA), resulting in lower health care expenditures. Hence, in what follows, we examine the responsiveness of household health care expenditures to remittance and other sources of household income according to whether the household has any type of health care coverage.

\section{D) Responsiveness of Health Care Expenditures by Health Care Coverage}

A significant portion of the Mexican population has either health insurance coverage through their jobs or through PROGRESA/Oportunidades -an ongoing anti-poverty program offering cash transfers to poor families in Mexico conditional on their participation in health and

\footnotetext{
${ }^{18}$ Complete results are available from the authors.
} 
nutrition programs. Because of the close link between household income and having basic health care needs covered, our last objective is to learn how, once we account for household income, remittances are used to finance health care expenditures conditional on having or lacking some kind of health insurance or health care coverage. With that purpose, we distinguish between households according to whether or not they have some kind of health care coverage through their employment or through special government programs.

All working individuals are asked whether they receive any health care benefits through their jobs and, if so, whether their health care needs (and, in turn, those of their eligible family members) are met by public medical services from IMSS, ISSTE, PEMEX, etceteras, or by private medical services. Approximately 42 percent of households in our sample fall in this category. Additionally, households report whether they receive any transfers from PROGRESA. Households participating in PROGRESA are required to participate in health and nutritional programs. ${ }^{19}$ About 14 percent of households in our sample participate in PROGRESA and only 1 percent of households receive health benefits though the employment of a household member and participate in PROGRESA. If the household has health insurance coverage through work or via participation in PROGRESA, it is labeled as "insured". Households that do not enjoy such coverage are labeled as "uninsured”.

Results from the estimations by household health care coverage are presented in Table 6. Uninsured households spend a greater share of increases in remittance income on health related expenditures than insured households. In particular, households lacking any health care coverage spend approximately 7 pesos out of a 100 peso increment in remittance income, 
whereas households with health care coverage spend only 5 pesos. This is reasonable given that household with health care coverage are likely to enjoy access to cheaper health care services. Furthermore, they help us understand why lower-income households in Table 5 -more likely to be eligible for PROGRESA- display a lower elasticity of health care expenditures with respect to remittance income than their higher income counterparts.

Finally, as in Tables 4 and 5, the figures in Table 6 confirm the fact that health care expenditures exhibit a higher responsiveness to increases in remittance income than to increases in other sources of household income. Indeed, uninsured households spend 2.6 pesos of a 100 peso increment in other sources of household income on health care relative to 7 pesos in the case of an increase in remittance income. Likewise, households with some kind of health care coverage spend 1.7 pesos of a 100 peso increment in other sources of household income on health care, as opposed to 5 pesos in the case of an increase in remittance income.

\section{Final Remarks}

In this study we model the impact of remittance income on Mexican households' health care expenditures while taking into account the potential endogeneity of remittances as well as the discrete and continuous nature of health care expenditures. We find that remittances increase both the likelihood of incurring health care expenditures and the level of expenditures undertaken. In particular, six pesos of every 100 peso increment in remittance income are spent on health. While remittances may then be considered to have a small impact on household health care expenditures, a case can be made that these inflows substantially increase health care

\footnotetext{
${ }^{19}$ Since our data refer to 2002, no families at the time were enrolled in other government programs described earlier, such as Seguro Popular.
} 
spending. Remittance-receiving households get an average of 6,109 pesos per quarter in remittances which, given the marginal effect of remittance income on health care expenditures, raise health care expenditures by 367 pesos, i.e. a 50 percent increase. In that regard, remittances are an economically significant determinant of health care expenditures. Furthermore, remittances are also important in driving health care expenditures when compared to other sources of household income. After all, the sensitivity of health care expenditures to variations in the level of international remittances is almost three times greater than its responsiveness to changes in other sources of household income, suggesting that emigrants may have a say in how remittance funds sent home are spent.

We also find remittance income has a significantly greater influence in shaping the health care expenditures of households in higher income groups relative to lower-income households. In particular, a 100 peso increment in remittance income raises the health care expenditures of households in the top half of the income distribution by 7 pesos, whereas a similar increment in remittances only raises the health care expenditures of households in the bottom income half by about 4 pesos. This finding may be due to a combination of liquidity constraints on the part of lower-income households, the scarcity of health care services in the areas that low income households reside and/or to participation of lower-income households in government programs that provide health care at zero or greatly reduced costs. We explore that last possibility further by examining the sensitivity of health care expenditures to remittance income according to household health care coverage. We find that households lacking any health care coverage exhibit greater remittance income sensitivity. In particular, a 100 peso increment in remittance income among those without health care coverage increases expenditures by 7 pesos, somewhat 
more than the 5 pesos spent by households who are covered through their jobs or through PROGRESA. Hence remittances may contribute to equalization in the usage of health care services by households with and without some kind of health care coverage by helping finance the health care expenditures of families lacking any type of health care coverage.

Given current and projected declines in remittance flows, it is important that policy makers brace for reductions in the usage and accessibility of health care services. This decline is likely to be greater than what might ordinarily be found in recession periods due to the finding that the elasticity of health care expenditures out of remittances exceeds that of non-remittance income. Furthermore, given the greater reliance on remittance income to finance health care expenditures of families lacking some kind of health care coverage, the decline in remittances may particularly hit households that need them the most.

To conclude, we would like to note that, while expenditures on health care may constitute a good human capital investment, greater health care expenditures may not translate into better health outcomes due to factors we are unable to account for with our data. For instance, households' life styles, diets and exercise regimes -all factors we lack information on, may be an overriding determinant of their health outcomes, irrespective of household's usage of health care services. Yet, the potential role of remittance income on health should not be dismissed as even non-health care related expenditures financed via remittances -such as investments in improved housing, water delivery systems, food refrigeration, and other durable goods, can also lead to improved health outcomes (Duryea, López-Córdova and Olmedo 2005). As such, the analysis herein reinforces the potential for remittance income to promote household well-being. 


\section{References}

Ando, A and Franco Modigliani. 1957. “Tests of the Life Cycle Hypothesis of Saving,” Bull. Oxford University.

Angrist, J. D. and A. Krueger. 2001. "Instrumental Variables and the Search for Identification: From Supply and Demand to Natural Experiments” Journal of Economic Perspectives, 15(4): 69-85.

Basmann, R. L. 1960. “On finite sample distributions of generalized classical linear identifiability test statistics" Journal of the American Statistical Association, 55(292): 650-659.

Baum, C. F., M. E. Schaffer, and S. Stillman. 2002. "Instrumental variables and GMM: Estimation and testing” Working paper no. 545, Department of Economics, Boston College. Available at: http://fmwww.bc.edu/ec-p/WP545.pdf

Bound, J., Jaeger D. A. and R. M. Baker. 1985. "Problem with Instrumental Variables Estimation when the Correlation between the Instruments and the Endogenous Explanatory Variable is Weak" Journal of the American Statistical Association, 90(430): 443-450.

Brown, Ricard P. C. 1997. "Estimating Remittance Functions for Pacific Island Migrants" World Development, 25(4): 613-626.

Cox, Donald, Zekeriya Eser, and Emmanuel Jimenez. 1998. "Motives for Private Transfers Over the Life Cycle: An Analytical Framework and Evidence for Peru.” Journal of Development Economics, 55(1): 57-80.

Duan, Naihua, Willard G. Manning, Jr. Carl N. Morris and Joseph P. Newhouse. 1983. “A Comparison of Alternative Models for the Demand for Medical Care" Journal of Business \& Economic Statistics, 1(2): 115-126.

Duryea, Suzanne, Ernesto López-Córdova and Alexandra Olmedo. 2005. "Migrant Remittance and Infant Mortality: Evidence from Mexico.” Unpublished manuscript.

Frank, Reanne and Robert A. Hummer. 2002. "The Other Side of the Paradox: The Risk of Low Birth Weight among Infants of Migrant and Nonmigrant Households within Mexico.” International Migration Review, 36(3): 746-765.

Frenk, Julio, Sepúlveda, Jaime, Gómez-Dantés, Octavio, and Felicia Knaul. 2003. “Evidencebased Health Policy: Three Generations of Reform in Mexico.” The Lancet, 362 (November 15), pp. 1667-71. 
Friedman, Milton. 1957. A Theory of the Consumption Function. Princeton: Princeton University Press.

Funkhouser, Edward. 1995. "Remittances from International Migration: A Comparison of El Salvador and Nicaragua.” Review of Economics and Statistics, 77(1): 137-46.

Grossman, Michael. 1972. "On the Concept of Health Capital and the Demand for Health" Journal of Political Economy, 80(2): 223-255.

Hay, Joel W. and Randall J. Olsen. 1984. "Let Them Eat Cake: A Note Comparing Alternative Models of the Demand for Medical Care” Journal of Business \& Economic Statistics, 2(3): 279-282.

Hildebrandt, Nicole and David J. McKenzie. 2004. "The Effects of Migration on child Health in Mexico.” Unpublished manuscript, Stanford University.

Hoddinott, John. 1994. "A Model of Migration and Remittances Applied to Western Kenya" Oxford Economic Papers, 46(3): 459-76.

Kanaiaupuni, Shawn Malia, and Katherine M. Donato. 1999. "Migradollars and Mortality” The Effects of Migration on Infant Survival in Mexico.” Demography, 36(3): 339-353.

Leland, Hayne. E. 1968. "'Saving and Uncertainty: The Precautionary Demand for Saving." Quarterly Journal of Economics, 82: 465-473.

Levitt, Peggy. 1997. "Transnationalizing Community Development: The Case of Migration Between Boston and the Dominican Republic." Nonprofit and Voluntary Sector Quarterly, 26(4): 509-526.

López Córdova, Ernesto. 2004. "Globalization, Migration and Development. The Role of Mexican Migrant Remittances.” Mimeo. Inter-American Development Bank.

Manning, Willard G. 1998. "The Logged Dependent Variable, Heteroscedasticity, and the Retransformation Problem”, Journal of Health Economics, 17: 283-295.

Migration Policy Institute. 2007. "Variable Impacts: State-level Analysis of the Slowdown in the Growth of Remittances to Mexico," in Migration Facts, September 2007, No. 19.

Mullahy, John. 1998. "Much Ado About Two: Reconsidering Retransformation and the TwoPart Model in Health Econometrics” Journal of Health Economics, 17: 247-281.

Murrugarra, Edmundo. 2002. “Public Transfers and Migrants' Remittances: Evidence from the Recent Armenian Experience.” World Bank Economists’ Forum, 2: 25-47. 
Newey, W. 1985. "Generalized Method of Moments Specification Testing” Journal of Econometrics, 29, 229-256.

Perez-Stable E.J., Slutkin G., Paz E.A., and P.C. Hopewell. 1986. "Tuberculin Reactivity in United States and Foreign-born Latinos: Results of a Community-based Screening Program” American Journal of Public Health, 76(6): 643-646.

Ravallion, Martin and Lorraine Dearden. 1988. “Social Security in a 'Moral Economy': An Empirical Analysis for Jav" Review of Economics and Statistics, 70(1): 36-44.

Rozelle, Scott; Taylor, J. Edward and Alan DeBrauw. 1999. "Migration, Remittances, and Agriculture Productivity in China” The American Economic Review, 89(2): 287-291.

Sargan, J.D. 1958. “The Estimation of Economic Relationships Using Instrumental Variables” Econometrica, 26: 393-415.

Schrieder, Gertrud and Beatrice Knerr. 2000. "Labour Migration as a Social Security Mechanism for Smallholder Households in Sub-Saharan Africa: The Case of Cameroon" Oxford Development Studies, 28(2): 223-36.

Secretaría de Salud. 2002. Síntesis Ejecutiva: Poblaciones de las Instituciones Prestadoras de Servicios de Salud de Mexico: Definición y Construcción. Mexico.

Secretaría de Salud. 2008. Seguro Popular at: www.seguro-popular.salud.gob.mx/

Stark, Oded. 1982. "Research on Rural-to-Urban Migration in LDCs: The Confusion Frontier and Why We Should Pause to Rethink Afresh" World Development, 10(1): 63-70.

Taylor, J. Edward. 1992. "Remittances and Inequality Reconsidered: Direct, Indirect, and Intertemporal Effects” Journal of Policy Modeling, 14(2): 187-208.

Valero-Gil, Jorge N. 2008, "Remittances and the household's expenditures on health,” mimeo, Universidad Autonoma de Nuevo Leon, Monterrey, Mexico.

Wooldridge, Jeffrey M. 2003. Introductory Econometrics: A Modern Approach, 2e, Thomson South-Western. 
Table 1

Motive for Remitting to Mexico

\begin{tabular}{lc}
\hline Primary Motive & Share \\
\hline Food and Maintenance & 25.64 \\
Health Care expenses & 21.23 \\
Construction or Repair of House & 4.03 \\
Debt Payment & 2.58 \\
Purchase of Consumer Goods & 2.09 \\
Other & 1.08 \\
Savings & 0.88 \\
Purchase of House or Lot & 0.58 \\
Education Expenses & 0.37 \\
Start/Expand a Business & 0.19 \\
Purchase of Agriculture Inputs & 0.19 \\
Purchase of Livestock & 0.19 \\
Recreation & 0.13 \\
Purchase of Vehicle & 0.04 \\
Finance a Special Event & 0.03 \\
Purchase of Tools & 0.01 \\
Unknown & 16.22 \\
\hline
\end{tabular}

Notes: Author's tabulations using the MMP118. 
Table 2

Income Sources

\begin{tabular}{|c|c|c|c|c|c|c|}
\hline \multirow{2}{*}{ Income Sources } & \multicolumn{2}{|c|}{ All } & \multicolumn{2}{|c|}{ Lower Half of HHs } & \multicolumn{2}{|c|}{ Upper half of HHs } \\
\hline & $\begin{array}{c}\% \mathrm{HH} \\
\text { reporting }\end{array}$ & Mean & $\begin{array}{c}\% \mathrm{HH} \\
\text { reporting }\end{array}$ & Mean & $\begin{array}{c}\% \mathrm{HH} \\
\text { reporting }\end{array}$ & Mean \\
\hline Total Income & 100 & 16141 & 100 & 6496 & 100 & 25683 \\
\hline Job Earnings & 71 & 14876 & 58 & 6005 & 83 & 21054 \\
\hline Business Earnings & 42 & 7945 & 45 & 2908 & 39 & 13745 \\
\hline Property Returns & 3 & 5933 & 2 & 2837 & 4 & 7408 \\
\hline Income Transfers & 35 & 4257 & 45 & 2385 & 25 & 7559 \\
\hline Capital Returns & 6 & 5776 & 5 & 1630 & 8 & 8196 \\
\hline Income Transfers from Abroad & 5 & 6109 & 8 & 6061 & 2 & 6284 \\
\hline
\end{tabular}

Notes: Mean figures for each of the categories are reported in pesos.

Source: INEGI, 2002 Encuesta Nacional de Ingresos y Gastos de los Hogares. 
Table 3

Household Health Care Expenditures by Demographic Characteristics

\begin{tabular}{|c|c|c|}
\hline Likelihood of Incurring Health Care Expenditures & Proportion & t-statistic \\
\hline All HHs & 0.58 & \\
\hline \multicolumn{3}{|l|}{ By Area where Household is Located } \\
\hline $\begin{array}{l}\text { Household is located in rural area } \\
\text { Household is not located in rural area }\end{array}$ & $\begin{array}{l}0.52 \\
0.59\end{array}$ & $-7.69 * * *$ \\
\hline \multicolumn{3}{|l|}{ By Head of Household } \\
\hline $\begin{array}{l}\text { Household is Headed by Female } \\
\text { Household is not Headed by Female }\end{array}$ & $\begin{array}{l}0.54 \\
0.58\end{array}$ & $-4.12^{-} * * *$ \\
\hline \multicolumn{3}{|l|}{ By Education Attainment } \\
\hline $\begin{array}{l}\text { Less Educated Household Heads } \\
\text { More Educated Household Heads }\end{array}$ & $\begin{array}{l}0.56 \\
0.59\end{array}$ & $-3.13^{* * *}$ \\
\hline \multicolumn{3}{|l|}{ By Income } \\
\hline $\begin{array}{l}\text { Household in Bottom Half } \\
\text { Household in Upper Half }\end{array}$ & $\begin{array}{l}0.52 \\
0.62\end{array}$ & $-12.48^{* * *}$ \\
\hline \multicolumn{3}{|l|}{ By Remittance Receipt } \\
\hline $\begin{array}{l}\text { Household Does not Receive Remittances } \\
\text { Household Receives Remittances }\end{array}$ & $\begin{array}{l}0.57 \\
0.69\end{array}$ & $-7.73 * * *$ \\
\hline Average Health Care Expenditures & Mean & t-statistic \\
\hline All HHs & 796 & \\
\hline \multicolumn{3}{|l|}{ By Area where Household is Located } \\
\hline $\begin{array}{l}\text { Household is located in rural area } \\
\text { Household is not located in rural area }\end{array}$ & $\begin{array}{l}685 \\
834\end{array}$ & $-8.41^{* * *}$ \\
\hline \multicolumn{3}{|l|}{ By Head of Household } \\
\hline $\begin{array}{l}\text { Household is Headed by Female } \\
\text { Household is not Headed by Female }\end{array}$ & $\begin{array}{l}642 \\
831\end{array}$ & -0.73 \\
\hline \multicolumn{3}{|l|}{ By Education Attainment } \\
\hline $\begin{array}{l}\text { Less Educated Household Heads } \\
\text { More Educated Household Heads }\end{array}$ & $\begin{array}{l}753 \\
874\end{array}$ & $-5.71^{* * *}$ \\
\hline \multicolumn{3}{|l|}{ By Income } \\
\hline $\begin{array}{l}\text { Household in Bottom Half } \\
\text { Household in Upper Half }\end{array}$ & $\begin{array}{c}486 \\
1059\end{array}$ & $-{ }^{-}-$ \\
\hline \multicolumn{3}{|l|}{ By Remittance Receipt } \\
\hline $\begin{array}{l}\text { Household Does not Receive Remittances } \\
\text { Household Receives Remittances }\end{array}$ & $\begin{array}{c}775 \\
1106\end{array}$ & $-4.80 * * *$ \\
\hline
\end{tabular}

Notes: Figures for average health care expenditures are in pesos. The hypothesis being tested is $\mathrm{H}_{0}$ : [mean (household receives remittances) - mean (household does not receive remittances)] $=0$. The alternative hypothesis is: $\mathrm{H}_{\mathrm{A}}$ : [mean (household receives remittances) - mean (household does not receive remittances) $\neq \neq 0$. *** Signifies statistically different from zero at the $1 \%$ level or better, **at the $5 \%$ level or better and *at the $10 \%$ level or better.

Source: INEGI, 2002 Encuesta Nacional de Ingresos y Gastos de los Hogares. 
Table 4: Impact of Remittance Income on All Health Care Expenditures

\begin{tabular}{|c|c|c|c|c|c|c|}
\hline \multirow{2}{*}{ Independent Variables } & \multicolumn{3}{|c|}{ Two Part Model without IVs } & \multicolumn{3}{|c|}{ Two Part Model with IVs } \\
\hline & Coefficient & S.E. & Marginal Effect & Coefficient & S.E. & Marginal Effect \\
\hline \multicolumn{7}{|l|}{ Second Part } \\
\hline Remittance Income & $0.0001 * * *$ & 7.93E-06 & 0.0470 & $0.0001 * * *$ & 1.10E-05 & 0.0612 \\
\hline Income Excluding Remittances & $3.46 \mathrm{E}-05^{* * *}$ & 1.37E-06 & 0.0187 & $3.50 \mathrm{E}-05^{* * *}$ & $1.41 E-06$ & 0.0192 \\
\hline Female Headed Household & -0.0144 & 0.0420 & -22.8398 & -0.0106 & 0.0429 & -21.4124 \\
\hline Household Size & -0.0230 & 0.0156 & -15.4337 & -0.0217 & 0.0160 & -15.7632 \\
\hline No. of Young Kids & $0.1230 * * *$ & 0.0230 & 72.9658 & $0.1198 * * *$ & 0.0237 & 72.6328 \\
\hline No. of Elderly Members & $0.2666 * * *$ & 0.0315 & 145.9961 & $0.2509 * * *$ & 0.0322 & 139.1058 \\
\hline No. of Members with College Education & 0.0293 & 0.0294 & 22.3285 & 0.0189 & 0.0300 & 18.7991 \\
\hline No. of Members with HS Education & 0.0142 & 0.0165 & 8.4857 & 0.0099 & 0.0169 & 7.4787 \\
\hline No. of Working Members in Mexico & $-0.0363 * *$ & 0.0181 & -0.3473 & $-0.0349 *$ & 0.0185 & 0.6401 \\
\hline Rural Household & -0.0496 & 0.0401 & -61.9059 & $-0.0829 * *$ & 0.0413 & -78.4183 \\
\hline Percent Migration & $0.0672 * * *$ & 0.0147 & 57.8912 & $0.0555^{* * *}$ & 0.0154 & 53.3432 \\
\hline Per Capita GDP & $-8.82 \mathrm{E}-06$ & $6.26 \mathrm{E}-06$ & 0.0017 & $-1.06 \mathrm{E}-05^{*}$ & $6.35 \mathrm{E}-06$ & 0.0013 \\
\hline Observations & \multicolumn{3}{|c|}{9608} & \multicolumn{3}{|c|}{9187} \\
\hline Significance & \multicolumn{3}{|c|}{ F-statistic $=99.92$ with Prob $>F=0.0000$} & \multicolumn{3}{|c|}{ F-statistic $=92.57$ with Prob $>F=0.0000$} \\
\hline \multicolumn{7}{|l|}{ First Part } \\
\hline Remittance Income & 4.45E-05*** & 6.37E-06 & - & $0.0001 * * *$ & 7.57E-06 & - \\
\hline Income Excluding Remittances & $7.69 \mathrm{E}-06 * * *$ & 9.19E-07 & - & $7.75 \mathrm{E}-06 * * *$ & 9.40E-07 & - \\
\hline Female Headed Household & $-0.0558 * *$ & 0.0253 & - & $-0.0556 * *$ & 0.0258 & - \\
\hline Household Size & $-0.0157 *$ & 0.0097 & - & $-0.0181^{*}$ & 0.0099 & - \\
\hline No. of Young Kids & $0.0605 * * *$ & 0.0148 & - & $0.0601 * * *$ & 0.0152 & - \\
\hline No. of Elderly Members & $0.0383^{* *}$ & 0.0191 & - & $0.0365^{*}$ & 0.0195 & - \\
\hline No. of Members with College Education & 0.0303 & 0.0194 & - & $0.0338 *$ & 0.0197 & - \\
\hline No. of Members with HS Education & 0.0061 & 0.0103 & - & 0.0093 & 0.0106 & - \\
\hline No. of Working Members in Mexico & $0.0597 * * *$ & 0.0115 & - & $0.0604 * * *$ & 0.0117 & - \\
\hline Rural Household & $-0.1315^{* * *}$ & 0.0242 & - & $-0.1294 * * *$ & 0.0248 & - \\
\hline Percent Migration & $0.0911 * * *$ & 0.0093 & - & $0.0914 * * *$ & 0.0097 & - \\
\hline Per Capita GDP & $2.10 \mathrm{E}-05^{* * *}$ & 3.89E-06 & - & $2.22 \mathrm{E}-05^{* * *}$ & 3.93E-06 & - \\
\hline Observations & \multicolumn{3}{|c|}{16810} & \multicolumn{3}{|c|}{16074} \\
\hline Significance & \multicolumn{3}{|c|}{ Wald Chi-sq $=513.80$ with Prob $>$ Chi2 $=0.0000$} & \multicolumn{3}{|c|}{ Wald Chi-sq $=504.49$ with Prob $>$ Chi2 $=0.0000$} \\
\hline \multicolumn{7}{|c|}{ Correlation of Instruments with Remittance Income } \\
\hline F-test for distance & \multicolumn{3}{|c|}{-} & \multicolumn{3}{|c|}{$F(1,16061)=6.16$ with Prob $>F=0.0131$} \\
\hline F-test for distance \& wages & \multicolumn{3}{|c|}{-} & \multicolumn{3}{|c|}{$\mathrm{F}(2,16061)=4.37$ with Prob $>\mathrm{F}=0.0126$} \\
\hline \multicolumn{7}{|l|}{ Over-identification Test of Instruments } \\
\hline Basmann-LIML Test & \multicolumn{3}{|c|}{-} & \multirow{2}{*}{\multicolumn{3}{|c|}{$\begin{array}{l}\text { Chi-sq(1) }=0.206 \text { with P-value }=0.6496 \\
\text { Chi-sq }(1)=0.207 \text { with P-value }=0.6495\end{array}$}} \\
\hline Sargan $N * \mathrm{R}$-sq Test & & - & & & & \\
\hline
\end{tabular}

Notes: *** Statistically different from zero at the $1 \%$ level, **at the $5 \%$ level or better and *at the $10 \%$ level or better. The regression includes a constant. 
Table 5

Two Part Model of the Impact of Remittance Income on All Health Care Expenditures by Household Income Level

\begin{tabular}{|c|c|c|c|c|c|c|}
\hline \multicolumn{7}{|c|}{ Lower-income households } \\
\hline \multirow{2}{*}{ Independent Variables } & \multicolumn{3}{|c|}{ Without IVs } & \multicolumn{3}{|c|}{ With IVs } \\
\hline & Coefficient & S.E. & Marginal Effect & Coefficient & S.E. & Marginal Effect \\
\hline \multicolumn{7}{|l|}{ Second Part } \\
\hline Remittance Income & $9.72 \mathrm{E}-05 * * *$ & 9.80-E06 & 0.0304 & $0.0001 * * *$ & $1.29 \mathrm{E}-05$ & 0.0433 \\
\hline Income Excluding Remittances & 7.34E-05*** & 8.47E-06 & 0.0232 & 7.13E-05*** & 8.68E-06 & 0.0239 \\
\hline $\begin{array}{l}\text { Observations } \\
\text { Significance }\end{array}$ & \multicolumn{3}{|c|}{ F-statistic $=19.87$ with Prob $>F=0.0000$} & \multicolumn{3}{|c|}{ F-statistic $=17.18$ with Prob $>F=0.0000$} \\
\hline \multicolumn{7}{|l|}{ First Part } \\
\hline Remittance Income & 4.86E-05*** & $7.42 \mathrm{E}-06$ & - & $7.70 \mathrm{E}-05^{* * *}$ & 8.53E-05 & - \\
\hline Income Excluding Remittances & $2.49 \mathrm{E}-05^{* * *}$ & 4.94E-06 & - & $3.05 \mathrm{E}-05^{* * *}$ & 5.05E-06 & - \\
\hline Observations & \multirow{2}{*}{\multicolumn{3}{|c|}{$\begin{array}{c}8550 \\
\text { Wald Chi-sq }=211.22 \text { with Prob }>\text { Chi2 }=0.0000\end{array}$}} & \multicolumn{3}{|c|}{8150} \\
\hline Significance & & & & Wald Chi-sq = & 2.71 with $\mathrm{P}$ & $\mathrm{b}>$ Chi2 $=0.0000$ \\
\hline \multicolumn{7}{|c|}{ Higher-income households } \\
\hline \multirow{2}{*}{ Independent Variables } & \multicolumn{3}{|c|}{ Without IVs } & \multicolumn{3}{|c|}{ With IVs } \\
\hline & Coefficient & S.E. & Marginal Effect & Coefficient & S.E. & Marginal Effect \\
\hline \multicolumn{7}{|l|}{ Second Part } \\
\hline Remittance Income & $6.04 \mathrm{E}-05^{* * *}$ & $1.47 \mathrm{E}-05$ & 0.0613 & $7.18 \mathrm{E}-05^{* * *}$ & 2.53E-05 & 0.0705 \\
\hline Income Excluding Remittances & $2.66 \mathrm{E}-05^{* * *}$ & 1.66E-06 & 0.0199 & $2.76 \mathrm{E}-06^{* * *}$ & $1.70 \mathrm{E}-06$ & 0.0207 \\
\hline $\begin{array}{l}\text { Observations } \\
\text { Significance }\end{array}$ & \multicolumn{3}{|c|}{$\begin{array}{c}5110 \\
\text { F-statistic }=38.54 \text { with } \text { Prob }>F=0.0000\end{array}$} & \multicolumn{3}{|c|}{$\begin{array}{c}4899 \\
\text { F-statistic }=37.10 \text { with Prob }>F=0.0000\end{array}$} \\
\hline \multicolumn{7}{|l|}{ First Part } \\
\hline Remittance Income & $5.87 \mathrm{E}-05^{* * *}$ & $1.58 \mathrm{E}-06$ & - & $5.76 \mathrm{E}-05^{* * *}$ & $2.00 \mathrm{E}-05$ & - \\
\hline Income Excluding Remittances & $5.75 \mathrm{E}-06^{* * *}$ & 1.14E-06 & - & $5.49 \mathrm{E}-06 * * *$ & 1.16E-06 & - \\
\hline Observations & \multicolumn{3}{|c|}{8260} & \multicolumn{3}{|c|}{7924} \\
\hline Significance & \multicolumn{3}{|c|}{ Wald Chi-sq $=215.37$ with Prob $>$ Chi2 $=0.0000$} & \multicolumn{3}{|c|}{ Wald Chi-sq $=207.82$ with Prob $>$ Chi2 $=0.0000$} \\
\hline
\end{tabular}

Notes: *** Signifies statistically different from zero at the $1 \%$ level, **at the $5 \%$ level or better and *at the $10 \%$ level or better. The regression includes a constant, along with all the regressors in Table 4. 
Table 6

Two Part Model of the Impact of Remittance Income on All Health Care Expenditures by Health Care Coverage

\begin{tabular}{|c|c|c|c|c|c|c|}
\hline \multicolumn{7}{|c|}{ Uninsured Households } \\
\hline \multirow{2}{*}{ Independent Variables } & \multicolumn{3}{|c|}{ Without IVs } & \multicolumn{3}{|c|}{ With IVs } \\
\hline & Coefficient & S.E. & Marginal Effect & Coefficient & S.E. & Marginal Effect \\
\hline \multicolumn{7}{|l|}{ Second Part } \\
\hline Remittance Income & $7.53 \mathrm{E}-05^{* * *}$ & 9.37E-06 & 0.0484 & $9.29 \mathrm{E}-05 * * *$ & 1.39E-05 & 0.0673 \\
\hline Income Excluding Remittances & 3.97E-05*** & 2.12E-06 & 0.0255 & $3.99 \mathrm{E}-06 * * *$ & 2.17E-06 & 0.0260 \\
\hline $\begin{array}{l}\text { Observations } \\
\text { Significance }\end{array}$ & \multicolumn{3}{|c|}{$\begin{array}{c}4643 \\
\text { F-statistic }=48.87 \text { with Prob }>F=0.0000\end{array}$} & \multicolumn{3}{|c|}{$\begin{array}{c}4481 \\
\text { F-statistic }=45.20 \text { with Prob }>F=0.0000\end{array}$} \\
\hline \multicolumn{7}{|l|}{ First Part } \\
\hline Remittance Income & $3.77 \mathrm{E}-05^{* * *}$ & 7.47E-06 & - & $5.92 \mathrm{E}-05^{* * *}$ & 9.77E-06 & - \\
\hline Income Excluding Remittances & $1.46 \mathrm{E}-05 * * *$ & 1.67E-06 & - & $1.50 \mathrm{E}-05^{* * *}$ & 1.72E-06 & - \\
\hline $\begin{array}{l}\text { Observations } \\
\text { Significance }\end{array}$ & \multicolumn{3}{|c|}{$\begin{array}{c}7674 \\
\text { Wald Chi-sq }=368.75 \text { with Prob }>\text { Chi2 }=0.0000\end{array}$} & \multicolumn{3}{|c|}{$\begin{array}{c}7397 \\
\text { Wald Chi-sq }=363.43 \text { with Prob }>\text { Chi2 }=0.0000\end{array}$} \\
\hline \multicolumn{7}{|c|}{ Insured Households } \\
\hline \multirow{2}{*}{ Independent Variables } & \multicolumn{3}{|c|}{ Without IVs } & \multicolumn{3}{|c|}{ With IVs } \\
\hline & Coefficient & S.E. & Marginal Effect & Coefficient & S.E. & Marginal Effect \\
\hline \multicolumn{7}{|l|}{ Second Part } \\
\hline Remittance Income & $7.10 \mathrm{E}-05^{* * *}$ & $1.50 \mathrm{E}-05$ & 0.0442 & $7.73 \mathrm{E}-05^{* * *}$ & $1.80 \mathrm{E}-05$ & 0.0517 \\
\hline Income Excluding Remittances & 3.35E-05*** & 1.83E-06 & 0.0161 & $3.40 \mathrm{E}-05^{* * *}$ & 1.89E-06 & 0.0166 \\
\hline $\begin{array}{l}\text { Observations } \\
\text { Significance }\end{array}$ & \multicolumn{3}{|c|}{$\begin{array}{c}4965 \\
\text { F-statistic }=57.11 \text { with Prob }>F=0.0000\end{array}$} & \multicolumn{3}{|c|}{4706} \\
\hline \multicolumn{7}{|l|}{ First Part } \\
\hline Remittance Income & $5.44 \mathrm{E}-05^{* * *}$ & $1.23 \mathrm{E}-05$ & - & $6.52 \mathrm{E}-05^{* * *}$ & $1.22 \mathrm{E}-05$ & - \\
\hline Income Excluding Remittances & $6.59 \mathrm{E}-06 * * *$ & 1.18E-06 & - & $6.60 \mathrm{E}-06^{* * *}$ & $1.21 \mathrm{E}-06$ & - \\
\hline $\begin{array}{l}\text { Observations } \\
\text { Significance }\end{array}$ & \multicolumn{3}{|l|}{ 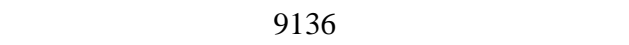 } & \multicolumn{3}{|c|}{8677} \\
\hline
\end{tabular}

Notes: *** Signifies statistically different from zero at the $1 \%$ level, **at the $5 \%$ level or better and *at the $10 \%$ level or better. The regression includes a constant, along with all the regressors in Table 4. 


\section{Appendix Tables}

Table A

Means and Standard Deviations of Variables Used in the Regression Analysis

\begin{tabular}{lcc}
\hline Variables & Mean & S.D. \\
\hline Any Health Care Expenditures & 0.5651 & 0.4958 \\
All Health Care Expenditures (excluding zeros) & 795.5646 & 2398.4960 \\
Any Remittance Income & 0.0508 & 0.2195 \\
Remittance Income (excluding zeros) & 6109.4080 & 5254.7980 \\
Income Including Remittances & 16141.01 & 14212.42 \\
Income Excluding Remittances & 15720.80 & 14292.44 \\
Female Headed Household & 0.1983 & 0.3987 \\
Household Size & 4.2053 & 2.0765 \\
No. of Young Kids & 0.6238 & 0.8828 \\
No. of Elderly Members & 0.2410 & 0.5459 \\
No. of Members with College Education & 0.2557 & 0.6334 \\
No. of Members with HS Education & 1.2610 & 1.2424 \\
No. of Members with Less than HS & 2.2511 & 1.7790 \\
No. of Working Members in Mexico & 2.8528 & 1.7596 \\
Rural Household & 0.2820 & 0.4500 \\
Percent Migration & 1.6668 & 1.1621 \\
Per Capita GDP (in thousands of pesos) & 5210.825 & 2789.501 \\
Distance to the U.S. in Kilometers & 1060.2150 & 538.6577 \\
Average wages at U.S. destination state & 745.5891 & 46.2537 \\
\hline
\end{tabular}

Notes: Mean figures for monetary categories are reported in pesos, unless otherwise specified.

Source: INEGI, 2002 Encuesta Nacional de Ingresos y Gastos de los Hogares. 
Table B

Tobit Model of Remittance Income

\begin{tabular}{lcccc}
\hline Variables & Coefficient & S.E. & $\begin{array}{c}\text { Partial Effect on the } \\
\text { Probability of Being } \\
\text { Uncensored }\end{array}$ & $\begin{array}{c}\text { Partial Effect on } \\
\text { the Conditional } \\
\text { Expectation }\end{array}$ \\
\hline Income Excluding Remittances & & & $-2.01 \mathrm{E}-06$ & -0.0115 \\
Female Headed Household & $-0.3753^{* * *}$ & 0.0326 & 0.0174 & 102.5033 \\
Household Size & $2852.9290^{* * *}$ & 545.1051 & 0.0032 & 18.0925 \\
No. of Young Kids & $588.1620^{* * *}$ & 213.4584 & 0.0039 & 22.4039 \\
No. of Elderly Members & $728.3222^{* *}$ & 334.9896 & 0.0075 & 43.2368 \\
No. of Members with College Education & $1405.5710^{* * *}$ & 394.5033 & 0.0007 & 3.9204 \\
No. of Members with HS Education & 127.4462 & 604.9462 & 0.0022 & 12.4856 \\
No. of Working Members in Mexico & $405.8889^{*}$ & 246.9485 & -0.0044 & -25.3098 \\
Rural Household & $-822.7876^{* * *}$ & 259.0353 & 0.0230 & 135.7644 \\
Percent Migration & $3780.8030^{* * *}$ & 518.2615 & 0.0198 & 113.7187 \\
Per Capita GDP & $3696.8450^{* * *}$ & 230.3217 & $1.11 \mathrm{E}-06$ & 0.0063 \\
Distance to the U.S. in Kilometers & $0.2064^{*}$ & 0.1126 & $-8.08 \mathrm{E}-06$ & -0.0463 \\
Average wages at U.S. destination state & $-1.5054^{* *}$ & 0.6067 & 0.0001 & 0.4388 \\
Total Observations & $14.2644^{* *}$ & 6.1466 & & \\
Uncensored Observations & & & 85074 & \\
LR Chi2 & & & 955.74 & \\
Prob $>$ Chi-sq & & & 0.0000 & \\
\hline
\end{tabular}

Notes: *** Signifies statistically different from zero at the $1 \%$ level, **at the $5 \%$ level or better and *at the $10 \%$ level or better. The regression includes a constant. 